Revista de la red interuniversitaria de estudios sobre las literaturas rioplatenses contemporáneas en Francia

$9 \mid 2013$

Homenaje a Ana María Barrenechea

\title{
Sarmiento's Secret
}

Diana Sorensen

\section{OpenEdition}

\section{Journals}

Electronic version

URL: http://journals.openedition.org/lirico/1166

DOI: $10.4000 /$ lirico. 1166

ISSN: 2262-8339

Publisher

Réseau interuniversitaire d'étude des littératures contemporaines du Río de la Plata

\section{Electronic reference}

Diana Sorensen, «Sarmiento's Secret», Cuadernos LIRICO [En línea], 9 | 2013, Puesto en línea el 01 septiembre 2013, consultado el 19 abril 2019. URL : http://journals.openedition.org/lirico/1166 ; DOI 10.4000/lirico.1166

This text was automatically generated on 20 April 2019

\section{(c) (i) (9)}

Cuadernos LIRICO está distribuido bajo una Licencia Creative Commons Atribución-NoComercialSinDerivar 4.0 Internacional. 


\title{
Sarmiento's Secret
}

\author{
Diana Sorensen
}

1 A while ago, I stumbled upon the traces of a secret. A secret about Sarmiento, one that was craftily removed from notice by Sarmiento's grandson Augusto Belin Sarmiento when he compiled his Obras completas

2 A secret produces a heuristic impulse: it propels us to ask questions; it incites us to discover and unveil what is hidden from view. In a radically humanistic move, it couples the heuristic and the hermeneutic, urging us to interpret its whys and wherefores. Secrets lead us to think about what it means to live among others, as we alternately hide and share information about ourselves. In the historical record, secrets can be thought of as operations that take place in the archive, where documents could be concealed, destroyed or misplaced. In other words, stumbling on a secret reminds us not only of the complexities of transmission, but, also, of the highly mediated nature of our relations with the past.

3 The secret in question concerns Sarmiento's time in the United States, and, specifically, at Harvard University. It may be known to some, because it appears in a book published by Emilio Carilla in 1963, and sent from the province of Tucumán as a gift to the library with a little note of thanks to "Widener Library, a quien mucho debe este libro." It was revealed in a 1952 article in the Hispanic American Historical Review by Alice Houston Luigi, as well as in the Harvard Alumni Magazine of the same year. ${ }^{1}$ There we learn that at the eleventh hour, Sarmiento was turned down for an honorary doctorate by the Harvard Board of Overseers, despite the fact that then President Thomas Hill and the Corporation had voted to award him and three others honorary doctorates in June 1867.

4 Biographers have made much of Sarmiento's Michigan honorary degree: why was the prospect of one from Harvard never discussed, not even by his enemies, of whom he always had more than a few? That this is more than an oversight is attested to by the labors of his grandson, Augusto Belin Sarmiento, editor of the first edition of his Obras completas, decreed by a law of 1884 , during Roca's presidency. Here we have a grandson busily covering up mention of this failed attempt to gain Harvard's recognition. Belin Sarmiento went as far as to cut and paste letters so as to omit its mention: he conceals 
references to Sarmiento's anticipated degree and in one baffling case compresses two letters (one of 1865, the other of 1867), in order to remove a revealing passage. In Sarmiento scholarship it is only mentioned in the article I cited above, and in a 1970 essay by Michael Rockland, author of an excellent edition of Sarmiento's Travels in the United States in $1847 .^{2}$ Only in much later Sarmiento scholarship-such as Rockland's article - are there references to this aborted degree. It was information withheld, blocked from the record. Now, over 200 years since the event, how unseemly it would be to play a gotcha on our hero. Instead, I'd like to speculate on the meaning of this doctorate in its contexts, and, perhaps, here at Harvard, where I teach, to make a modest gesture of atonement.

5 I begin with the textual question. In the Longfellow archives and in Mary Mann's letters we find reference to this failed attempt : there is absolutely no mention of the Harvard doctorate in the Obras completas, even though volumes XXIX and XXX contain many letters exchanged during Sarmiento's mission as Minister Plenipotentiary in 1865-68. The key Mann letters are part of a batch of twenty-four letters from the Will Seymour Monroe bequest of Henry Barnard papers to New York University. The key one is dated April 10, 1867, and in it Mrs. Mann writes to Dr. Barnard about a "little project" "of hers": "to procure a degree of LL.D. from Harvard for our friend Mr. Sarmiento." ${ }^{3}$ Aware that only "influential gentlemen" can successfully present the papers to the Corporation, she asks for Henry Barnard's help. Mary Mann has already checked in with Harvard University President Thomas Hill (1862-88), with Louis Agassiz and with Henry Longfellow. In an undated letter held in the Longfellow papers at Houghton Library, Mary Mann is even more explicit about her goals, and I will quote significant portions of the letter because they allow us to think about the question of the secret :

I have also a request to make. I know from Mr. Sarmiento's history, which is a very interesting one, that it would be of incalculable advantage to his influence at home if he could have a complimentary degree of Law from Harvard University.

The universities of S. America have an iron rule under which they refuse a degree to any one however learned, who has not from a boy been through the whole course of their studies. (Mr. Sarmiento knows more about legislation than any one in any of their Republics)...

The Buenos Ayres University is hostile to him because he has made strenuous efforts to get this law abrogated - besides, Buenos Ayres is jealous of his influence. He is a prophet that is not fully estimated in his own country. ${ }^{4}$

Another letter to Barnard presumes that the degree is almost certain:

Dr. Hill, Prof. Agassiz and Dr. Gould have had a talk about the degree and send me word that I may consider it as good as done. Prof. Longfellow, who knows Mr. S. personally, also wishes it - but why not have a degree from Yale, too, since degrees are so valuable to him. (... $)^{5}$

Later in the letter Mrs. Mann says that people should call him "Dr. Sarmiento," and reports that he says such a title "will be more valuable to him than the Presidency."

Yet this was not meant to be: Harvard's archives show that while on June 15, 1867, the Corporation had voted a Doctor of Laws for Domingo Francisco Sarmiento, Benjamin Peirce, Stephen Salisbury and Thomas Aspinewall, five days later a Committee of the Board of Overseers recommended that a degree be given to only one of the four, Benjamin Peirce, a notable Harvard mathematician. All we find by way of explanation in the Harvard Archives reads as follows: "The committee on the Honorary degrees reported recommending that the votes of the Corporation in reference to Honorary degrees be respectfully returned to the Corporation for further consideration...". On June 
29 the Corporation records indicate: "Voted, that the Degree of Doctor of Laws be conferred upon Benjamin Peirce."6

There is nothing surprising about concealing a disappointment of this nature. What I'd like to do is to use it to open up the meaning of the secret as discredit at this point in Sarmiento's career, and to reflect on his North American adventures. What would an honorary degree from Harvard have meant to Sarmiento in 1867, and why did he and Mary Mann consider it possible ? That an honorary degree would convey prestige is a safe and even obvious assumption, even though when he first arrived in Cambridge Sarmiento confused the name of the town with the name of the university. In due course he made the distinction between Harvard and Cambridge, and recognized Harvard's standing.

Further, one can clearly see that the legitimacy and recognition garnered abroad would be trophies to be taken back home as validation in a hostile environment. This has been made amply clear with regard to the French and American reviews of his Facundo. ${ }^{7}$ But in the late 1860's a Harvard degree took on other meanings derived from the cultural and political context of Sarmiento's second stay in the United States. Although he had been appointed Minister Plenipotentiary, his standing in Argentina was far from solid. As a self-taught man with scant formal schooling, he had been undermined throughout his life by enemies who cast his effortful self-invention as fraud. Juan Bautista Alberdi made much of this in his Las ciento y una of 1852 ; in the 1860's, the eminent letrado Juan María Gutiérrez, then President (Rector) of the Universidad de Buenos Aires, was refusing to grant Sarmiento a university degree. Mary Mann's correspondence refers to these conflicts, and all of us who have followed the tensions between arms and letters in Sarmiento's life are aware of how arduously he negotiated between them, and how he strove to be what I have called un letrado de acción (Sorensen 2002 : xv), striving to mediate between civilization and barbarism, legal order and the power of force, the chaos of an emerging nation and the laborious construction of its institutions. As Minister Plenipotentiary, Sarmiento's efforts were focused on education, with single-minded determination evident in volume XIX and in Ambas Américas, the short-lived journal through which the north-south conversation was begun on this topic. This second trip not only confirmed the initial conclusion of the 1847 visit, which had convinced Sarmiento that in the United States he had found a utopian laboratory for nation building. Now, in the 1860's, he had the opportunity to work directly with the great educators of the time, as can be seen in his correspondence. Aside from dealing with figures such as Henry Barnard and Senator Sumner, Sarmiento got to establish significant relationships with poets, scientists and philosophers in the Cambridge-Concord area, many of them with ties to Harvard University : small wonder, then, that he had high hopes for its recognition. Thanks to Mary Mann's introductions, he visited Emerson at his Concord home, and got to know Longfellow, Ticknor, Agassiz, Gould and Harvard President Hill. Longfellow had been Smith Professor of French and Spanish until 1854, and his good Spanish impressed Sarmiento. Upon discovering that Ticknor's and Longfellow's command of Hispanic literature excluded familiarity with South American works, Sarmiento embarked on an effort to have works sent to the north, deposited in libraries such as Harvard's, The Boston Athenaeum, the Astor Library, and the Library of Congress. He wrote to José Mármol, the Argentine Minister in Brazil, urging him to donate his books for this cause; he also asked for Juan María Gutiérrez's help. In these exchanges, I submit, we can discern an important early moment in the history of Latin American Studies in the United States. Other even more concrete initiatives sprung from 
Sarmiento's Cambridge friendships: Benjamin Apthorp Gould, the eminent Harvard astronomer, was invited by President Sarmiento in 1870 to set up the first observatory in South America, in Córdoba, where he remained until 1885. And then there were the many teachers who made the voyage to South America with different degrees of success, many of whom were referred by Mary Mann, indefatigable champion of Sarmiento's efforts. As invitations and exchanges multiplied, Sarmiento was persuaded that he was finally gaining the recognition so bitterly denied by his enemies at home. In a telling letter to Aurelia Vélez Sarsfield, he delights in the signs of respect, and contrasts them with the many humiliations suffered at home, “...tanto me han hecho sentir mis inferioridades mis amigos, estos pasados años...”. In fact, Sarmiento reads in a constant counter-punctual mode in an economy that trades insult in his homeland for legitimation in the US. Of the numerous examples, I shall cite just one : asked to sign a guest book at the Cambridge Library using a pen once handled by General Grant, he boasts, "Ya ve Ud. que no soy tan cualquiera, aunque sea Ministro de la República Argentina, que nadie sabe dónde está..." When Mary Mann reported on her efforts, Sarmiento confessed that a Harvard degree would certainly break his opponents' weapons, but, more importantly, it would be worth more than their own degrees. So having his candidacy rejected by the Overseers put a sudden and painful end to a long-established process of external validation that Sarmiento had counted on since managing to get Facundo reviewed in Paris in 1847.

In closing, let me return to the hermeneutics of the secret, and speculate that it is perhaps the fragility of legitimation and honor that the secret was meant to conceal, and that it now reveals. It was a family secret orchestrated by a grandson busily excising passages in the correspondence transcribed in the massive Obras completas that were to be an early monument. Those stray letters bequeathed by Will Seymour Monroe have made the revelation possible.

And yet, there was a striking reversal in the system of exchange that managed honor and humiliation: shortly after the bad news from Harvard reached him, Sarmiento learned of his election to the Argentine presidency. No doubt, ample compensation for the disappointment. And yet, at Harvard, where I teach, so many years later, I'd like to think of this brief essay as belated recognition, even, I daresay, making amends for that mysterious vote that withheld the coveted Doctor of Laws.

\section{BIBLIOGRAPHY}

\section{Works Cited}

Houston Luigi, Alison. "Letters of Sarmiento and Mary Mann 1865-1876, Part I." Hispanic American Historical Review, 32, 2, May 1952 (187-211).

Rockland, Michael. "Henry Wadsworth Longfellow and Domingo Faustino Sarmiento." Journal of Interamerican Studies and World Affairs, 12, 2, April 1970 (271-279).

Rockland, Michael . Sarmiento's Travels in the United States in 1847. Princeton, NJ : Princeton University Press, 1970. 
Sarmiento, Domingo Faustino. Obras completas. Buenos Aires : Editorial Luz del Día, 1948.

Sorensen Goodrich, Diana. Facundo and the Construction of Argentine Culture. Austin, Texas : The University of Texas Press, 1996.

Sorensen, Diana (ed.). Sarmiento. Obras selectas. Madrid : Fundación Biblioteca Universal, 2002.

\section{NOTES}

1. Mrs Mann's idea is first announced in a letter to Dr. Barnard dated April 10, 1867 : "You will be interested, I know, in a little project of mine and Dr Gould's. It is to procure a degree of LL.D from Harvard for our friend Mr. Sarmiento. I know it will be invaluable for him at home." In Alice Houston Luigi, "Letters of Sarmiento and Mary Mann 1865-1876, Part I," in : Hispanic American Historical Review (May 1952 : 204).

2. See "Henry Wadsworth Longfellow and Domingo Faustino Sarmiento," in: Journal of Interamerican Studies and World Affairs (April 1970 : 278). For Rockland's book about Sarmiento's travels see Sarmiento's Travels in the United States in 1847 (1970).

3. Quoted above in Hispanic American Historical Review (1952 : 204- 205).

4. Undated letter, presumably of Spring 1867, Longfellow papers, Houghton Library, Harvard University. Quoted in Michael Rockland, "Henry Wadsworth Longfellow and Domingo Faustino Sarmiento" (1970: 278).

5. In Houston Luigi (1952: 205).

6. "Harvard University. Corporation records : minutes, June 15 and June 29, 1867. UAI 5.30, Volume XI, Harvard University Archives."

7. For more on this, see my "Facundo's Travels to the Metropolitan Centers," in my Facundo and the Construction of Argentine Culture (1996: 83-98).

8. In : Domingo Faustino Sarmiento, Obras completas, vol. XXIX (1948: 73).

\section{ABSTRACTS}

This essay speculates on the implications of keeping a secret in the Sarmiento archive: Harvard's refusal to grant him an honorary degree in 1867 . The essay studies how the process of obtaining the degree was set in motion, how it was aborted, and what it meant in the context of Sarmiento's location at home and abroad.

Este ensayo reflexiona sobre las implicaciones de un dato ausente de los archivos de Sarmiento : la negativa de Harvard de otorgarle un doctorado honorífico en 1867. El ensayo estudia cómo se puso en marcha y cómo fracasó el proceso para que obtuviera el título, y qué significaba esto para el posicionamiento de Sarmiento tanto en su país como en el extranjero.

Cet essai aborde les implications d'une donnée bannie des archives de Sarmiento: le refus de l'université de Harvard de lui octroyer un Doctorat honorifique en 1867. L'essai étudie de quelle manière fut engagé le processus pour l'obtention du diplôme, comment il échoua, et sa signification dans le cadre du positionnement de Sarmiento dans son pays et à l'étranger. 
INDEX

Mots-clés: Sarmiento, Doctorat en Droit, Université de Harvard, légitimité, reconnaissance Keywords: Degree of Doctor of Laws, Harvard University, legitimacy, recognition

Palabras claves: Doctorado en Leyes, Universidad de Harvard, legitimidad, reconocimiento

\section{AUTHOR}

DIANA SORENSEN

Harvard University

Sorensen@fas.harvard.edu 